\title{
MATHEMATICS ANXIETY AND ACHIEVEMENT AMONG SECONDARY SCHOOL STUDENTS
}

\author{
Effandi Zakaria, Normalizam Mohd Zain, Nur Amalina Ahmad and Ayu Erlina \\ Department of Educational Methodology and Practice, \\ Faculty of Education, Universiti Kebangsaan Malaysia, Malaysia
}

Received 2012-08-29, Revised 2012-08-22; Accepted 2012-08-29

\begin{abstract}
Research has shown that mathematics achievement in students is influenced by psychological factors such as mathematics anxiety. Weaknesses among students in learning mathematics in particular will affect the efforts of various sectors in making Malaysia a fully developed nation by 2020. The purpose of this study was to determine mathematics anxiety and mathematics achievement among secondary school students in Selangor, Malaysia. The research examined the differences in mathematics anxiety according to gender as well as the differences in mathematics achievement of students based on the level of mathematics anxiety. The study involved195 Form Four students (86 male and 109 female). The instrument used to measure differences was adapted from the Fennema-Sherman Mathematics Attitudes Scale. The data was analyzed using Statistical Package for the Social Sciences (SPSS) to determine the mean, frequency, t-test and one-way ANOVA. The findings of the study indicated that there is mathematics anxiety among secondary school students. The t-test showed that the mean difference between mathematics anxiety and gender is not significant. The ANOVA test showed that there were significant differences in achievement based on the level of mathematics anxiety. Thus, math anxiety is one factor that affects student achievement. Therefore, teachers should strive to understand mathematics anxiety and implement teaching and learning strategies so that students can overcome their anxiety.
\end{abstract}

Keywords: Mathematics Anxiety, Mathematics Achievement, Gender

\section{INTRODUCTION}

Mathematics is a core subject in secondary schools. The study of mathematics was established to produce a competent person who is able to apply knowledge of mathematics in everyday life effectively and responsibly in solving problems and making decisions. Weaknesses among students in learning mathematics in particular will affect the efforts of various sectors in making Malaysia a fully developed nation by 2020. Mathematics anxiety is a psychological dimension of learning that is important for educators to identify. Much research has been done to investigate the extent of mathematics anxiety in primary school (Sherman and Wither, 2003; Jackson and Leffingwell, 1999; Steele and Arth, 1998; Yuksel-Şahin, 2008) and at the secondary level (Mohamed and Tarmizi, 2010; Karimi and Venkatesan, 2009; Khatoon and Mahmood, 2010). Research has shown that mathematics achievement in students is influenced by psychological factors such as mathematics anxiety. In the mathematical context, it appears that many students who are weak in mathematics worry while attempting to use math skills to solve problems (Mohamed and Tarmizi, 2010; Arem, 2003; Rahim, 2002; Tobias, 1995). The findings of Marsh and Tapia (2002) indicate that students with low levels of math anxiety feel more excited, more confident and highly motivated to learn mathematics when compared to students who have high anxiety levels.

Math anxiety is loosely regarded as feelings of fear, avoidance and dread when dealing with any situation relating to mathematics. Tobias (1995) defined mathematics anxiety as a feeling of tension and anxiety that appears when someone is engaged in the manipulation of figures to solve mathematical problems in both academic and daily-life situations. It is easy to forget math equations and to lose confidence when one is experiencing mathematics anxiety. Mathematics anxiety is found to be associated with beliefs. The research of Tobias revealed that there are many female students at the university level who change their majors to avoid mathematics. This has happened not because these

Corresponding Author: Effandi Zakaria, Department of Educational Methodology and Practice Faculty of Education, Universiti Kebangsaan Malaysia, Malaysia 
women have a lower intellectual level than men, but because of the belief factor among female students in mathematics. Female students reported that they were not able to understand and solve mathematical problems that they had previously studied. Mathematics anxiety was defined as the level of discomfort that occurs among students in response to situations involving mathematical tasks, which is seen as a threat to their self-ability (Trujillo and Hadfield, 1999). It is described as a construct that involves cognitive and affective behaviors. This construct is related to personality type, negative attitudes toward mathematics, math avoidance, math background, teaching behavior, achievement levels, lack of confidence and negative experiences in school (Harper and Daane, 1998; Hembree, 1990; Sloan et al., 2002). Puteh (2002) describes mathematics anxiety as a repetitive process that is based on information gathered by individuals from their surroundings. This information is accumulated and becomes the personal experience of individuals, which finally informs their beliefs toward mathematics. These beliefs produce behavioral situations to escape mathematics because of an overriding fear of being unable to master mathematics. According to Puteh, teachers, peers and parents are responsible for triggering anxiety among students of mathematics. If students perceive that "mathematics is difficult" during their formative years, mathematics anxiety will be triggered. Due to the presence of mathematics anxiety, such students will strive to escape from any situation that involves mathematics. This will strengthen their belief that they are not capable and lack the knowledge to engage in mathematics and they will continue to lose confidence in their math skills as a result. Although these students will continue their course of study in mathematics, most likely failure will again occur because of their prescribed belief system.

According to Arem (2009), mathematics anxiety is an emotional, mental and physical act related to the mathematical thinking and problem-solving process and resulting from uncomfortable past experiences related to mathematics. Feelings and experiences like this will further affect a student's ability to learn mathematics. Based on the study, students who have experienced disappointment in their mathematical abilities will have difficulty believing in their abilities in the future. Arem (2009) found that contributing factors to mathematics anxiety are bitter experiences in mathematics, social pressure and the expectation to achieve outstanding results, the desire to excel, myths about the study of math, societal gender stereotypes and negative self-talk. These factors give rise to feelings of deep shame for the student experiencing mathematics anxiety in the classroom setting. According to Arem, students with math anxiety will often appear preoccupied with something else to avoid meeting face-to-face with their teachers. They are afraid to look up in class and quickly panic when their name is called. They are also afraid to raise their hands and when the teacher is waiting for an answer from them, they become even more afraid.

\subsection{Mathematics Anxiety and Gender}

Several studies have been conducted to investigate the level of mathematics anxiety among male and female students. Some researchers have argued that females have higher mathematics anxiety than males (Salwani and Salleh, 2001; Woodard, 2004; Yuksel-Şahin, 2008; Karimi and Venkatesan, 2009; Khatoon and Mahmood, 2010). In addition, female students are often labeled as shy and this characteristic can harm their ability to learn. Male students were found to be more active in a wider range of social activities than female students (Khatoon and Mahmood, 2010). Yuksel-Şahin (2008) study on secondary school students in Turkey reported that the stereotypical view of this issue has a powerful impact. Female students believed boys were blessed with the advantage of mastering mathematics, while the boys felt they were better able to perform in mathematics when compared with their female counterparts. Such beliefs negatively affect the ability of female students and their initial assumptions about mathematics achievement can have a long-term impact on their math achievement. However, other studies do not support this theory. Based on several studies, some researchers have argued that there is no significant difference in mathematics anxiety between males and females (Marsh and Tapia, 2002; Elenchothy, 2007; Mohamed and Tarmizi, 2010).

\subsection{Mathematics Anxiety and Achievement}

According to Sherman and Wither (2003), a five-year study conducted on students from the age of 6 to the age of 10 revealed that the level of mathematics anxiety in students is strongly related to student achievement. This is supported by studies by Elenchothy (2007), which showed an inverse relationship between mathematics anxiety and student achievement. His findings were based on the results of Lower Secondary Assessments (PMR) for students in the district of Klang, Malaysia. This inverse relationship means that students with high mathematics anxiety will realize low achievement in mathematics. The results conform to the findings of Khatoon and Mahmood (2010); Yuksel-Şahin (2008) and Satake and Amato (1995). Students will often feel worried, tired and afraid or feel that mathematics is not important and will generally refuse to learn mathematics, even though it is the primary gateway to engineering, science and technology. According to Arem (2009), students with high mathematics anxiety levels engage in negative thinking about their self-ability. These students 
will exhibit less confidence in working with numbers and mathematical concepts through a problem-solving process. Zakaria (1997) also explained that students with high performance levels in mathematics have a positive attitude toward mathematics. This is in line with several researchers who reported that teachers' interest and selfconfidence play an important role in student success. A student who has a deep interest can be encouraged to work and train without being asked by the teacher. Interest and confidence in this aspect are very important in learning to reduce anxiety in mathematics and eventually being able to obtain good results on examinations. Thus, to determine math anxiety and its relationship to mathematics achievement among secondary school students, the research objectives are as follows:

- To determine the level of mathematics anxiety of secondary school students

- To determine the differences in mathematics anxiety of students by gender

- To determine the differences in mathematics achievement of students based on the level of mathematics anxiety

\section{MATERIALS AND METHODS}

A survey design was used in this study. The sample involved in this study was 195 secondary school students in Selangor, which consisted of 86 boys and 109 girls. The instrument used in this study to measure differences was the Fennema-Sherman Mathematics Attitudes Scale (FSMAS). A questionnaire was used to assess the level of anxiety in mathematics. The researchers used the FSMAS questionnaire, which was translated by Zakaria and Nordin (2008). This questionnaire has 12 items, consisting of 7 positive statements and 5 negative statements. The five-point Likert scale was used to measure the students' anxiety levels, with a "1"representing "strongly disagree" and a "5"representing "strongly agree," The coefficient of reliability of the instruments of this study is 0.92 . Meanwhile, student math achievement scores were measured using the Form Four Annual Examination.

\section{RESULTS}

The results showed that the overall mean was $\mathrm{M}=$ 2.87 , representing those who have moderate math anxiety. A t-test was conducted to compare the level of mathematics anxiety by gender. Results are shown in the table below (Table 1).

As the above table indicates, the mean score for male students' math anxiety was $1.99(\mathrm{~N}=86$, sd $=0.82)$, which was slightly lower than the mean score of $2.00(\mathrm{~N}=$ 109 , sd $=0.82$ ) obtained from female students.
Table 1. Differences in mathematics anxiety based on gender

\begin{tabular}{llllll}
\hline Gender & $\mathrm{N}$ & $\mathrm{M}$ & $\mathrm{Sd}$ & $\mathrm{t}-\mathrm{value}$ & $\mathrm{Sig}$ \\
\hline Male & 86.0 & 1.99 & 0.82 & -0.99 & 0.93 \\
Female & 109 & 2.00 & 0.82 & &
\end{tabular}

Note: Significant level $\mathrm{p}<0.05$

Table 2.Mean of mathematics achievement based on the level of mathematics anxiety

\begin{tabular}{lrrr}
\hline & \multicolumn{3}{c}{ Mathematics anxiety } \\
& High & Moderate & \multicolumn{1}{c}{ Low } \\
\hline Level of math anxiety & 65.00 & 66.00 & 64.00 \\
No. of students & 1.28 & 1.65 & 2.22 \\
\hline
\end{tabular}

Table 3. Differences in mean of mathematics achievement based on the level of mathematics anxiety

\begin{tabular}{lrrrll}
\hline & Sum of & \multicolumn{3}{c}{ Mean } & \\
& squares & df & square & F & Sig. \\
\hline Between group & 28.98 & 2 & 14.40 & 35.24 & $0.00^{*}$ \\
Within group & 78.94 & 192 & 0.41 & & \\
Total & 129.00 & 194 & & & \\
\hline Note: *Significant level $\mathrm{p}<0.05$ & & &
\end{tabular}

Note: *Significant level $\mathrm{p}<0.05$

Table 4. Post Hoc test TUKEYHSD

\begin{tabular}{lll}
\hline Mathematics anxiety & Difference in mean & Sig. \\
\hline High-moderate & -0.37 & $0.0003^{*}$ \\
High-low & -0.94 & $0.000^{*}$ \\
Moderate-low & -0.57 & $0.000^{*}$ \\
\hline
\end{tabular}

Note: *Significant level $\mathrm{p}<0.05$

A t-test was conducted to better support the finding that there was no significant difference in mathematics anxiety levels between boys and girls $(t=-0.09, p>0.05)$. Therefore, a null hypothesis was rejected. There is no significant difference in the level of mathematics anxiety according to sex. From the results of a descriptive statistical analysis, the obtained mean mathematics achievement of students based on mathematics anxiety levels is shown in the following table (Table 2).

The table above shows the mean of mathematics achievement based on the level of mathematics anxiety. To determine differences in mean mathematics achievement of students by level of anxiety, a one-way ANOVA test was performed. Results of the ANOVA test are shown in Table 3 below.

The table above shows that there are significant differences in mean of mathematics achievement scores based on the level of mathematics anxiety $(\mathrm{F}=35.20$, df $=2,194, \mathrm{p}<0.05)$. A null hypothesis was rejected.

To determine significant differences, a Tukey's Post Hoc test was conducted. The results can be seen in the following table (Table 4).

As shown in Table 4 there are significant differences in mathematics achievement between high and moderate anxiety, between high and low anxiety and between moderate and low anxiety. 


\section{DISCUSSION}

\subsection{Mathematics Anxiety in Secondary School}

The results showed that secondary school students' mathematics anxiety level in Selangor, Malaysia is at a moderate level. Although the students are not in their national examination year, their teacher always gives a monthly test. This finding supports a study conducted by Smith (2004), which found that students experience anxiety when they know that a test or task is coming. A test is an inevitable uncertainty and causes students to worry. This study was also supported by Bidin et al. (2003), who conducted a survey among Form Three students in Perlis, Malaysia and found that the students' overall anxiety level was moderate.

\subsection{Mathematics Anxiety by Gender}

This study found that there was no significant difference in mathematics anxiety levels of students according to gender. This may be due to similarities in students' academic backgrounds and their basic knowledge of mathematics. This finding is consistent with studies by Zettle and Raines (2000) and Rahim (2002), which determined that there is no relationship between mathematics anxiety andgender. However, these findings contradict the findings of Woodard (2004); Bidin et al. (2003); Salwani and Salleh (2001); Yuksel-Şahin (2008) and Karimi and Venkatesan (2009), all of which noted significant differences in mathematics anxiety according to gender, with female students exhibiting higher math anxiety than their male counterparts.

\subsection{Mathematics Achievement Based on Level of Mathematics Anxiety}

The findings also showed significant differences between students' mathematics achievements based on their math anxiety levels. Students who are high achievers have lower levels of anxiety, while lowachieving math students have high levels of anxiety. This is because high achievers have a strong understanding of mathematics and have more confidence than low achievers. These findings support the findings of Woodard (2004) and Karimi and Venkatesan (2009), who determined that students who have high anxiety levels tend to earn lower mathematics scores. Conversely, students who have low levels of anxiety tend to score higher in math.

\section{CONCLUSION}

Results reveal that there still exists mathematics anxiety among secondary school students. However, gender-related factors do not influence mathematics anxiety. This study also shows that there is a difference in mathematics achievement of students based on their level of mathematics anxiety. Therefore, teachers should strive to understand mathematics anxiety and implement teaching and learning strategies so that students can overcome their anxiety. Yuksel-Şahin (2008) suggests that teachers should be positive and supportive and should also employ teaching methods that empower students to develop healthy attitudes toward mathematics. In addition, Smith (2004) suggests that teachers demonstrate their own interest in mathematics in order to raise students' motivation in mathematics as a means of helping students reduce their math anxiety. Thus, this study has implications for all parties, including teachers, schools and parents, encouraging those with a vested interest in the success of their students to take into account math anxiety levels before determining effective and appropriate strategies when teaching and learning is carried out. In this way, it is hoped that the level of mathematics anxiety can be reduced.

\section{REFERENCES}

Arem, C.A., 2003. Conquering Math Anxiety. 2nd Edn., Brooks/Cole-Thomson Learning, Pacific Grove, ISBN-10: 0534386342, pp: 193.

Arem, C.A., 2009. Conquering Math Anxiety. 3rd Edn., Cengage Learning, Belmont, ISBN-10: 0495829404, pp: 215.

Bidin, J., N. Sharif and Z. Kassim, 2003. Kegelisahan matematik di kalangan pelajar menengah rendah di perlis. Proceedings of the 13th National Symposium of Mathematical Sciences, Mathematics Anxiety Among Secondary School, Perlis.

Elenchothy, D., 2007. Kebimbangan matematik dan hubungannya dengan pencapaian pelajar tingkatan empat di daerah Klang. M.Sc Thesis, Universiti Putra Malaysia.

Harper, N.W. and C.J. Daane, 1998. Causes and reduction of math anxiety in preservice elementary teachers. Action Teacher Educ., 19: 29-38.

Hembree, R., 1990. The nature, effects and relief of mathematics anxiety. J. Res. Math. Educ., 21: 33-46.

Jackson, C.D. and R.J. Leffingwell, 1999. The role of instructors in creating math anxiety in students from kindergarten through college. National Council Teachers Math., 92: 583-586. 
Karimi, A. and S. Venkatesen, 2009. Mathematics anxiety, mathematics performance and academic hardiness in high school students. Int. J. Educ. Sci., 1: 33-37.

Khatoon, T. and S. Mahmood, 2010. Mathematics anxiety among secondary school students in India and its relationship to achievement in mathematics. Eur. J. Soc. Sci., 16: 75-86.

Marsh, G.E. and M. Tapia, 2002. Feeling good about mathematics: Are there sex differences? Proceedings of the Annual Meeting of the Mid-South Educational Research Association, Nov. 6-8, Chattanooga, TN, pp: 1-12.

Mohamed, S.H. and R.A. Tarmizi, 2010. Anxiety in mathematics learning among secondary school learners: A comparative study between Tanzania and Malaysia. Proc. Soc. Behav. Sci., 8: 498-504. DOI: 10.1016/j.sbspro.2010.12.068

Puteh, M., 2002. Qualitative research approach towards factors associated with mathematics anxiety. Proceeding of the 3rd International Mathematics Education and Society Conference, (MESC' 02), Centre of Research in Learning Mathematics, Copenhagen, pp: 1-5.

Rahim, M., 2002. Kajian kerisauan matematik dikalangan pelajar-pelajar diploma di kolej yayasan melaka. M.Sc Thesis, Universiti Kebangsaan Malaysia.

Salwani, T. and A. Salleh, 2001. Perkaitan antara kerisauan matematik dengan pencapaiannya di sebuah institusi pengajian teknikal. M.Sc Thesis, Universiti Kebangsaan Malaysia.

Satake, E. and P.P. Amato, 1995. Mathematics anxiety and achievement among Japanese elementary school students. Educ. Psychol. Measure., 55: 1000-1007.

Sherman, B.F. and D.P. Wither, 2003. Mathematics anxiety and mathematics achievement. Math. Educ. Res. J., 12: 138-150.
Sloan, T., C.J. Daane and J. Giesen, 2002. Mathematics anxiety and learning styles: What is the relationship in elementary preservice teachers. School Sci. Math., 102: 84-87.

Smith, M.R., 2004. Math anxiety: Causes, effects and preventative measures. M.Sc Thesis, Liberty University.

Steele, D.E. and A.A. Arth, 1998. Lowering anxiety in the math curriculum. Educ. Digest, 63: 18-24.

Tobias, S., 1995. Overcoming Math Anxiety. 1st Edn., W.W. Norton, ISBN-10: 0393313077, New York, pp: 260.

Trujillo, K.M. and O.D. Hadfield, 1999. Tracing the roots of mathematics anxiety through in-depth interviews with preservice elementary teachers. College Student J., 33: 219-219.

Woodard, T., 2004. The effects of math anxiety on postsecondary developmental students as related to achievement. Gender Age.

Yuksel-Sahin, F., 2008. Mathematics anxiety among 4th and 5th grade turkish elementary school students. Int. Elect. J. Math. Educ., 3: 179-192.

Zakaria, E. and N.M. Nordin, 2008. The effects of mathematics anxiety on matriculation students as related to motivation and achievement. Eurasia J. Math. Sci. Technol. Educ., 4: 27-30.

Zakaria, E., 1997. Sikap pelajar terhadap matematik tambahan: Hubungannya dengan pencapaian matematik. Classroom Teacher, 2: 22-25.

Zettle, R.D. and S.J. Raines, 2000. The relationship of trait and test anxiety with mathematics anxiety. College Student J., 34: 264-246. 